\title{
The environment
}

The background and origins of the environment as a political issue

A review of the ways in which the environment became a more prominent issue

Description and assessment of New Labour environmental policies after 1997

\section{DEFINING THE TERM 'ENVIRONMENT'}

The term 'environment' is a broad one and we need first to establish which aspects are covered here. For the purposes of this chapter, we will recognise the following meanings.

- Matters concerning the physical environment, including air and water quality, climate, noise, traffic congestion, health issues and the physical beauty of landscapes etc.

- Long-term concerns about bio-diversity, preservation of endangered species, the effects of earth changes which affect climate etc.

- Issues concerning the safety of foods etc., mainly dealing with the implications of genetically modified foods.

- Environmental issues which affect safety, such as the use of nuclear energy or mining.

- The question of preserving sources of energy and other resources, including the development of alternative forms of energy and recycling schemes.

These examples may omit some environmental concerns, but they represent a selection of the most important matters which have been considered by the British political system. 


\section{PRINCIPLES}

Environmental policy is very different to other issues in British politics. There are a number of reasons for this.

As a policy issue, it is very densely populated with pressure groups. Greenpeace and Friends of the Earth are well known examples, but there are many others concerned with a wide range of specialised areas. Furthermore, some of these groups have extremely large memberships. The National Trust and the Royal Society for the Protection of Birds (RSPB) are prominent examples. But there are many others such as the Council for the Protection of Rural England, the Countryside Alliance and Woodland Trust. If we consider local levels of political activities, there are still more, many of them temporary in nature. Groups exist to promote or prevent traffic management measures, airport building, changes in countryside use, building developments and the like.

Issues affecting the environment concern the political system at different levels. There are, as we have seen above, many local campaigns constantly being fought. In addition, issues may be regional or national, but, more often than not, are European and global in nature. Most environmental problems do not recognise political boundaries, so action by governments is rarely simple and cannot be conducted in isolation.

The environment is not normally considered to be a subject which is a vote winner or loser in elections. Although environmental issues remain on most people's list of concerns, it is not normally high and rarely influences voting behaviour. Political parties know this, so they do not consider it a high priority. Meanwhile, the British Green party has failed to gain a significant toe-hold in British political life, largely as a result of the first-past-the-post electoral system which discriminates against small parties. As we shall see below, some progress has been made in recent years, but this is slow and relatively modest.

\section{THE ORIGINS OF ENVIRONMENTAL CONCERNS}

Until the 1960s the environment scarcely appeared at all on the political agenda. There had been concerns about the health implications of pollution in the nineteenth and early twentieth century, but they were largely seen as isolated examples. They tended to be dealt with by the creation of inspectorates, which were set up to regulate the activities of individual industries. 
Two early pieces of legislation which signalled the end of an ad hoc approach to environmental issues were the Clean Air Acts of 1956 and 1968. This legislation applied to both individual households and to industry. They were concerned solely with air quality, but were the first signs of a national policy emerging.

In 1974 the Control of Pollution Act marked a further step towards a more comprehensive policy. This was both national and dealt with a wider variety of forms of pollution, adding water quality to air. At the same time the issue of pollution was brought onto the agenda of the European Community, with Germany leading the way in demanding European-wide anti-pollution standards.

These were some of the opening shots in the war against pollution and in the battle to bring environmental concerns to a higher place on the political agenda. During the late 1960s and 1970s a number of developments were important:

- Part of the New Left movement of the 1960s, which was concerned with the alienation of marginalised groups in society, became interested in environmental issues. Left-wing opponents of free-market capitalism, mainly among youth protest movements, saw it as exploiting the earth's physical environment as well as its workers and consumers. As members of this youth movement grew older, many of them retained the environmental concerns which they had developed in the 1960s.

- A larger amount of scientific evidence was emerging. Information gathered about links between air pollution and diseases such as cancer and asthma. Concerns about the increasing danger to many animal and plant species were growing. Scientists began to suspect that long-term changes in climate were taking place and were possibly the result of environmental degradation.

- The two oil price crises of the 1970s alerted the developed world to its over-reliance on a single source of energy. This led to a search for new sources of energy which would be both environmentally friendly (i.e. not fossil fuels) and renewable.

- New political groups were coming into existence in this period. The British Ecology party appeared and soon transformed itself into the Green Party. Friends of the Earth appeared as a world movement and soon became a huge pressure group with extensive funds and a large organisation for campaigning, publicity and scientific research. Greenpeace soon followed. Meanwhile, existing organisations such as the National Trust were turning themselves into campaign groups. 


\section{THE ENVIRONMENT BECOMES A MAJOR ISSUE}

Having drifted around the margins of British and European politics in the 1960s and 1970s, the environment moved closer to centre stage in the 1980s. The environmental concerns of the past were becoming more obviously acute and political action was clearly needed.

In Britain the issue was brought to the forefront of the agenda by the Conservative government of Margaret Thatcher. They seemed to be an unlikely candidate as guardian of the environment. As an apparent friend of capitalism, which was seen as the main culprit in environmental degradation, one would not have expected radical policies in this area. Yet progress was made in the mid-1980s.

In 1987 Her Majesty's Inspectorate of Pollution (HMIP) was set up. This was the first national organisation created to deal with environmental maters. They had powers to deal with both industry and local authorities in controlling air, water and waste pollution. In 1988 Thatcher herself made a landmark speech to the Royal Society, accepting that global warming was a serious problem for the future.

The years 1989-90 proved to be landmark ones in Britain. In 1989 the National Rivers Authority (NRA) was set up. In 1990 the Environment Protection Act was passed. This was the first piece of legislation to set universal standards of pollution control. They were to be administered by the NRA and the HMIP. Private and public bodies were bound by the targets and sanctions were introduced against transgressors. Any organisation which felt it could justify breaking the targets was forced to apply for special dispensation. Also in 1990 the Conservative government published a document entitled This Common Inheritance, the first comprehensive policy document to appear concerning sustainable development.

While these initiatives were taking place, the European Community were placing the environment onto their agenda. In 1987 the Single European Act was implemented. This Act made environmental protection one of the responsibilities of the Community, with voting on the issue in the Council of Ministers requiring unanimity to protect national interests.

In 1993 John Gummer became Environment Secretary. This was a key event as Gummer was an important environmental campaigner. He wished to build on the progress made in the 1980s. Gummer introduced air pollution targets, which began the process of reducing harmful car emissions, and instituted a policy for farmers to create environmentally sensitive areas, with grants to support them. Most importantly, however, he created the Environment Agency in 1995 by amalgamating the NRA and the HMIP. This large powerful 
body was to carry forward environmental policy and had extensive powers to enforce standards. Any developments which might have environmental consequences had to submit plans to the agency for approval.

\section{NEW LABOUR AND THE ENVIRONMENT}

Part of New Labour's 'third way' philosophy was to accept environmentalism as a key political issue. Although Blair's party is committed to supporting business, it argues that this can only be done provided environmental concerns are addressed. In other words, it contains a belief that industrial development and environmental concerns can be compatible, an idea which many campaigners see as impossible. The diversity of New Labour policies reflects the breadth of the issue in itself.

\section{Global involvement}

Two international treaties have set the scene of global concerns. These were the agreements at Rio de Janeiro in 1992 and the Kyoto agreement in 1997. The former was negotiated by the Conservative government of John Major and the latter by the Labour government, with John Prescott representing Britain, interestingly assisted by John Gummer who had led the Conservative environmental initiative earlier.

These two agreements aimed to make progress in cutting harmful emissions, known as greenhouse gases. The Rio accord, known as Agenda 21 placed a requirement on all participants to take measures to reduce emissions. However, the targets were too imprecise. At Kyoto, however, it was agreed that greenhouse gas emissions should be cut from 1990 levels by the following levels:

- USA: 7 per cent

- EU: 8 per cent

- Japan: 6 per cent

There is little doubt that the British government representatives played a leading role in these negotiations. Furthermore, the British commitment has been in excess of the targets set. New Labour sees itself as a more internationalist government than its predecessors and has attempted to move both the EU and the USA to a more radical position on the environment. In the case of the USA this has not been successful and President George Bush junior repudiated the Kyoto treaty early in 2002. His administration also largely ignored the 2002 Johannesburg conference on poverty and the environment. 


\section{Traffic and car pollution}

Although the Labour government since 1997 has claimed to be interested in reducing traffic levels and congestion in cities, its policies have failed to make significant progress. Road building programmes have not been cut back (despite fierce opposition from a variety of local anti-roads campaign groups). Indeed, when London Mayor Ken Livingstone announced the introduction of congestion charges in the city centre and proposed parking taxes, the government seemed remarkably hostile.

Labour has also dragged its feet on such issues as road tolls to reduce motorway traffic and a taxation system designed to reduce the use of largeengined cars which produce most pollution. Its 1998 Transport White Paper promised more spending on public transport to get cars off the road, in combination with a variety of proposals to introduce charges on motorists to deter car use. By 2002 little progress had been made and a new crisis in public transport threatened to de-rail (literally!) policy.

But the government's anti-emissions policy was most severely tested in the autumn of 2000. At that time there was a sharp rise in oil prices, and therefore also petrol prices. This caused a massive campaign against the high levels of duty on fuel which the government was levying (in its defence, the government could argue that the rise in fuel taxation had started under previous Conservative governments).

Gordon Brown was now in a dilemma over how to deal with the crisis. Fuel depots were being blockaded by protesters: the farmers and other rural interests were applying huge pressure and motorists were running out of fuel as the blockades prevented petrol getting to filling stations. Brown argued that high petrol duties were a key part of an integrated emissions policy. Indeed, he added, it was part of the country's Agenda 21 commitments.

In the event Brown made concessions to the protesters. Fuel duties were reduced and he gave a commitment to hold them down in the immediate future. Environmentalists were dismayed by Brown's apparent climbdown. Motorists, however, were pleased that the crisis had passed. Most agree that the government, Brown in particular, had failed its greatest environmental test.

\section{Farming and the countryside}

The Labour government reluctantly became mired in problems with the countryside after it came to office. It was dealing with the aftermath of the BSE crisis, which had devastated livestock farming when two further problems emerged. The first was the outbreak of foot and mouth disease in 2001. It took nearly a year before the epidemic subsided. During this period rural interests 
claimed that the crisis had been badly handled and was a sign that the government did not understand the problems of the countryside. The second was very much of the government's own making. It decided to allow parliament a free vote on whether to ban hunting with hounds (mainly foxhunting). This was seen as an attack by urban dwellers on the countryside.

The three problems which the government faced threw into focus the whole issue of the British countryside and rural life. John Prescott had already established a so-called 'right to roam', forcing landowners to open up footpaths and rights of way. The measure had been greeted with mixed feelings. It had also placed the countryside and the environment together by creating a new government department - the Department for the Environment, Food and Rural Affairs (DEFRA). Now the whole issue of the Common Agricultural Policy (CAP) had to be addressed.

Expenditure on the CAP was becoming excessive. Furthermore British agriculture was not benefiting greatly from it, while it seemed to be of most interest to the French, who were seen as being at the centre of the beef industry's problems over BSE. It was, therefore, decided in 2002 to tie together the two issues of agricultural subsidies and environmental measures in the countryside. Rural Affair Minister Alun Michael announced that some subsidies would be phased out. Under a new EU directive he is free to replace up to 20 per cent of subsidies with government grants to farmers in return for their becoming responsible for environmental protection. Such issues as the conservation of endangered species, river water quality, maintenance of meadows and hedgerows are to be included in the scheme.

At the same time the new department has additional funds available for the encouragement of organic farming. It is recognised that large-scale industrial farming is unlikely to have a future in the UK. Farmers here cannot compete in an increasingly free world market. Industrial farming is also seen as a danger to the countryside environment.

The issue over which Labour has created most difficulty for itself in this field concerns research into genetically modified (GM) foods. In 1998 the government decided to ban its commercial use and brought in regulations (which apply throughout the EU) to force food processors to declare whether GM ingredients have been used. However, Tony Blair himself is committed to the continued approval of research. This has angered campaigners, especially Greenpeace and Friends of the Earth, who want an outright ban. 


\section{NEW LABOUR: AN ASSESSMENT}

Despite its rhetoric, the Labour government which came to power in 1997 has a very mixed record on the environment. It has shown considerable global concerns and is widely praised for its attempts to preserve the Rio and Kyoto agreements on climate change. On the other hand its policies on transport have been less coherent. The commitments to reduce road traffic and improve public transport have not been maintained.

The main problems concern the government's difficulties in reconciling competing interests. The conflict between environmentalists and the motorists' lobby is a typical example. So too are those issues which create heated debate between farmers and rural interest groups and, in some cases, within the farming community itself. Its difficulties over what to do about GM foods is a typical example of the latter.

It may be that it will need a further advance by the Green Party and its allies to stimulate fresh interest. The Greens made an apparently famous 'breakthrough' in the elections to the European Parliament in 1995 by winning 15 per cent of the popular vote. It has also won seats in the Scottish Parliament and Welsh Assembly where proportional representation (PR) is being used. But these advances have been small and short lived. In terms of the popular vote the Greens have achieved little. Until they do, the government is unlikely to renew its commitment to the environment. As things stand, environmental campaigners are pleased by what they hear but are disappointed by what has been achieved.

\section{THE EUROPEAN UNION}

As we have seen, environmental protection, became an EU concern in 1987. Its jurisdiction lies in the following areas:

- The preservation of fish stocks in the seas around Europe. This is part of the Common Fisheries Policy (CFP).

- Control over sea pollution. Member states must conform to regulations concerning sewage and other potentially harmful releases into the sea.

- There is a scheme in place to encourage clean beaches. Coastal towns which can demonstrate minimum standards of cleanliness receive European awards.

- Under the Common Agricultural Policy, farmers must agree to certain environmental regulations in return for subsidies.

- Emissions controls over industries, notably chemicals and metals, are set by the EU. 
- There are European emissions control regulations on cars, lorries and all forms of transport.

- European targets for the cleanliness of rivers have been agreed.

- There are European controls over the hunting of species which are considered to be endangered.

\section{SAMPLE QUESTIONS}

1 Why has environmental policy remained relatively low on the British political agenda?

2 In what ways has membership of the European Union affected environmental policy in Europe?

3 Assess New Labour's claim to be a friend of the environment since

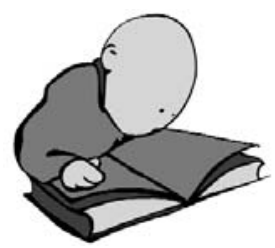
1997. 